\title{
Potensi Kandas Batuan berdasarkan Metode Markland, dan Zona Rawan Longsor di Daerah Kaliwader, Kecamatan Bener, Kabupaten Purworejo, Jawa Tengah
}

\author{
Sari Bahagiarti Kusumayudha ${ }^{\text {a) }}$, Azwar Thamrin, Heru Sigit Purwanto \\ Jurusan Teknik Geologi, Universitas Pembangunan Nasional "Veteran" Yogyakarta \\ ${ }^{a)}$ Email korespondensi: saribk@upnyk.ac.id
}

\begin{abstract}
ABSTRAK
Daerah penelitian secara administratif berada di Kecamatan Bener, Kabupaten Purworejo, Jawa Tengah. Secara geomorfologi, bentuk lahan daerah tersebut terdiri dari Perbukitan Struktural (S1), Lembah Homoklin (S2), Dataran Alluvial (F1), Tubuh Sungai (F2), dan Dataran Limpah Banjir (F3). Lito-stratigrafi daerah penelitian mulai dari batuan tertua, disusun oleh Satuan Breksi-vulkanik Kaligesing, Satuan Lava-andesit Kaligesing, kedua satuan berumur Oligosen Akhir hingga Miosen Awal, Satuan Batugamping-pasiran Sentolo berumur Miosen Tengah - Pliosen Awal (N14 - N19), dan Satuan endapan alluvial berumur recent. Di daerah penelitian juga dijumpai intrusi andesit berumur Oligosen Akhir - Miosen Awal. Struktur geologi berupa kekar dan sesar secara umum mempunyai orientasi Timurlaut - Baratdaya termasuk reverse left slip fault, dan Baratlaut Tenggara, merupakan right lateral slip fault. Dari hasil analisis kestabilan lereng terhadap enam lokasi lereng batu berdasarkan metode Markland, diketahui bahwa lereng Wadas berpotensi longsor tipe wedge failure dan planar slide, lereng Kaliwader 1 berpotensi longsor tipe wedge failure, lereng Kaliwader 2 berpotensi longsor tipe wedge failure, lereng Kaliwader 3 berpotensi longsor tipe wedge failure, lereng Kaliwader 4 tidak berpotensi longsor, dan lereng Ngargosari berpotensi terjadi longsoran tipe wedge failure dan tipe planar slide. Penanggulangan longsor dapat dilakukan dengan melakukan pelandaian lereng dan atau metode trap/terasering.
\end{abstract}

Kata Kunci: kandas batuan; metode markland; planar slide; wedge failure

\begin{abstract}
The research area is administratively located in District Bener, the Purworejo Regency, Central Java. Geomorphologically, the landform of the area consists of Structural Hills (S1), Homoklin Valley (S2), Alluvial Plain (F1), River Body (F2), and Floodplain (F3). Litho-stratigraphy of the study area from the oldest rock is composed of Kaligesing Volcanic Breccia, Kaligesing Lava-andesite Unit, the two units are of the late Oligocene to the Early Miocene, the Sentolo sandy limestone unit is Middle Miocene to Early Pliocene (N14N19), and recent alluvial sedimentary unit. In the study area also encountered Andesite intrusion of late Oligocene to Early Miocene. The geological structures of joints and faults are generally oriented Northeast Southwest including reverse left slip fault, and Northwest - Southeast that is right lateral slip fault. The results of stability analysis on six locations of slopes applying Markland method, it is known that the Wadas slope is potential of wedge failure and planar slide, the Kaliwader 1 slope is potential of wedge failure, the Kaliwader 2 slope is potential of wedge failure, the Kaliwader 3 slope is potential of wedge failure, the Kaliwader 4 slope is not potential for landslides, and the Ngargosari slope is potential to occur wedge failure and planar slide. Landslide mitigation can be done by lowering the slopes and / or terracing methods.
\end{abstract}

Keywords: markland method; planar slide; rock rock; wedge failure

\section{PENDAHULUAN}

Penataan lingkungan dan pengembangan wilayah di daerah bermorfologi perbukitan acap kali dihadapkan pada masalah kestabilan lereng yang dapat menimbulkan ancaman terjadinya longsor lahan. Longsor lahan merupakan salah satu penyebab kecelakaan fasilitas umum misalnya jalan dan pemukiman. Kondisi lereng yang tidak memenuhi kriteria keamanan dan tidak terpantau akan menjadi ancaman bagi masyarakat. Untuk itu diperlukan kajian, penyelidikan, dan penentuan potensi longsor yang dilakukan pada lereng - lereng alami yang memiliki banyak diskontuinitas. Sebagaimana diketahui, kehadiran bidang-bidang diskontinuitas pada umumnya menjadi salah satu pemicu terjadinya kekandasan lereng tersusun oleh batuan segar.

Penelitian ini dilakukan dengan tujuan untuk menganalisis kestabilan lereng dan menentukan potensi kekandasan batuan guna menunjang upaya penyusunan zona rawan longsor, dalam rangka mitigasi bencana di daerah penelitian sebagai landasan dalam pembangunan wilayah. Adapun lokasi daerah penelitian adalah di Daerah Kaliwader dan sekitarnya, Kecamatan Bener, Kabupaten Purworejo, Jawa Tengah, tampak pada Gambar 


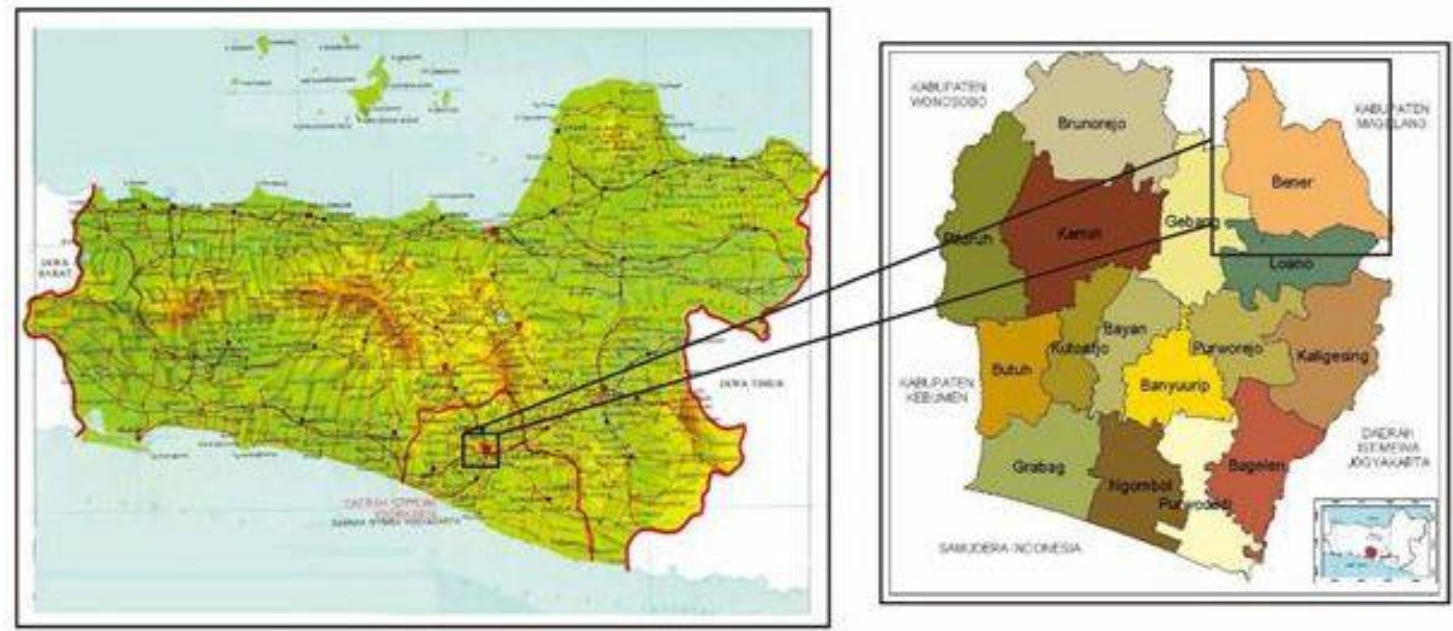

Gambar 1. Lokasi daerah penelitian

\section{METODE PENELITIAN}

Penelitian ini dilaksakan dengan memadukan metode-metode diskriptif, analitik, survei lapangan, dan uji laboratorium. Kegiatan yang dilakukan meliputi kajian terhadap data sekunder dan data primer. Data sekunder terdiri dari kepustakaan geologi regional, geologi teknik dari hasil penelitian terdahulu, dan citra satelit. Metode survei dilaksanakan untuk pemetaan geologi, pemetaan geomorfologi, identifikasi kejadian longsor, dan pengukuran kedudukan struktur geologi. Pengambilan sampel batuan dilakukan pada lokasi-lokasi terpilih, untuk analisis petrologi dan uji sifat fisik/mekanik di laboratorium. Selanjutnya dilakukan uji laboratorium terhadap sampel batuan untuk mengetahui sifat-sifat batuan, digunakan dalam penentuan potensi kekandasan batuan berdasarkan metode Markland.

Menurut Goodman (1989), gaya merupakan penyebab terjadinya gerakan. Gaya yang bekerja pada luas area tertentu disebut stress atau tegangan. Distribusi gaya yang bekerja pada suatu lereng dapat digambarkan sebagaimana pada Gambar 2.

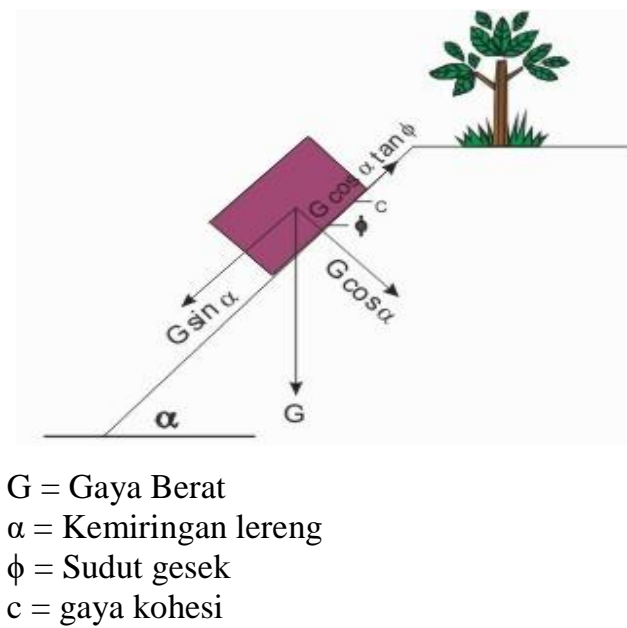

Gambar 2. Distribusi gaya bekerja pada lereng (Citrabuwana, et.al, 2016)

Menurut Hoek \& Bray (1981), lereng yang disusun oleh batuan keras memiliki karakter yang berbeda dengan lereng dibangun oleh tanah (Evans, 2006, Price, 2009 dalam Citrabuwana et al, 2016). Kestabilan lereng pada kondisi demikian sepenuhnya sangat ditentukan oleh kekuatan geser batuan. Kuat geser batuan pada umumnya dipengaruhi oleh kehadiran bidang-bidang lemah atau bidang diskontinuitas seperti halnya bidang perlapisan, kekar, rekahan, sesar, dan foliasi atau struktur geologi lainnya (Hoek \& Bray, 1981, Citrabuwana et.al, 2016, Kusumayudha \& Ciptahening, 2016). 
Untuk menentukan potensi kekandasan batuan pada lereng, khususnya yang dibangun oleh batuan segar dank eras, sebuah metode analitik oleh Markland (Hoek \& Bray, 1981) dapat diaplikasikan. Model kekandasan batuan pada lereng menurut Markland dalam Hoek \& Bray (1981) adalah sebagaimana dituangkan dalam Gambar 3.

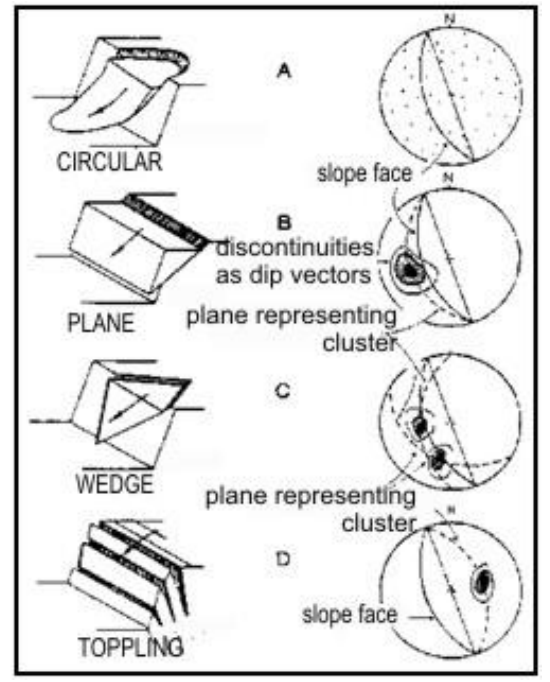

Gambar 3. Model proyeksi strereografi kekandasan lereng menurut Markland (Hoek \& Bray, 1981)

Berdasarkan Hoek \& Bray (1981), tipe-tipe kekandasan batuan dapat berupa planar slide, wedge, dan tople atau topling. Sementara itu ukuran kestabilan lereng ditetapkan berdasarkan faktor keamanannya. Secara umum penentuan nilai faktor keamanan adalah berdasarkan Persamaan 1:

$$
\text { Factor of Safety }(F S)=\frac{\text { Resisting Force }}{\text { Driving Force }}
$$

Resisting force adalah total gaya penahan, dan driving force merupakan total gaya penggerak. Apabila nilai faktor keamanan lebih besar dari 1 maka lereng dinyatakan aman atau stabul, bila faktor keamanan sama dengan 1 lereng dalam kondisi kritis, dan bila faktor keamanan kurang dari 1 maka lereng akan kandas (Hoek \& Bray, 1981; Franklin \& Dussault, 1989, Goodman, 1989, dalam Citrabuwana et al, 2016 dan dalam Kusumayudha \& Ciptahening, 2016).

\section{HASIL DAN PEMBAHASAN}

\subsection{Geomorfologi}

Geomorfologi daerah penelitian membentuk lahan perbukitan struktural, lereng homoklin, dataran aluvial, dan tubuh sungai. Perbukitan struktural memiliki orientasi memanjang Timur-Barat dan terpotong-potong oleh lembah-lembah hasil erosi, dipengaruhi struktur geologi berupa sesar dan kekar, dengan litologi dominan berupa batuan vulkanik klastik. Bentuk lahan lereng homoklin memiliki bentuk lembah memanjang Baratlaut Tenggara, dipengaruhi proses erosi, memiliki elevasi antara 150-200 meter dengan kelerengan miring-curam $\left(4^{\circ}-35^{\circ}\right)$. Bentuk lahan dataran alluvial dengan lereng landai atau hampir datar $\left(0^{\circ}-4^{\circ}\right)$, memiliki elevasi 112,5 150 meter. Tubuh sungai memiliki elevasi kurang lebih 150 meter dengan pola pengaliran sub-dendritik, bentuk lembah "V" hingga "U". Pola pengaliran di daerah penelitian sangat erat hubungannya dengan litologi, struktur geologi dan proses pelapukan.

\subsection{Geologi}

Susunan batuan di Daerah Kaliwader dan sekitarnya mulai dari yang tertua hingga paling muda, adalah Satuan breksi-vulkanik Kaligesing, Satuan lava-andesit Kaligesing, Satuan batugamping-pasiran Sentolo, dan endapan aluvial. Terdapat intrusi andesit yang menerobos hingga satuan lava Kaligesing.

Satuan breksi-vulkanik Kaligesing, pada bagian bawah didominasi breksi andesit dengan sisipan lava andesit. Sedangkan pada bagian atas didominasi breksi andesit, dengan sisipan batupasir vulkanik. Sifat pengendapan breksi adalah piroklastik dan laharik. Satuan ini diintrusi oleh retas yang menunjukkan struktur columnar joint. 
Satuan lava-andesit Kaligesing, didominasi oleh lava andesit, sisipan breksi andesit, dan ditemukan intrusi dengan struktur sheeting joint. Pada lava andesit, menunjukan struktur autobreccia yang terbentuk pada saat pembekuan lava, ditemukan juga struktur vesikuler dan skoria ditandai dengan lubang-lubang terbentuk akibat pelepasan gas selama pendinginan.

Satuan Batugamping-pasiran Sentolo, terdiri dari batugamping pasiran dan sisipan fragmen andesit. Pada batugamping pasiran sering ditemukan fragmen-fragmen lithic, komposisi allochem foram, skeletal, matrik kalsit, lumpur karbonat. Secara umum kemiringan satuan ini berarah barat daya, dengan kedudukan $\mathrm{N} 155^{\circ} \mathrm{E} /$ $5^{\circ}$. Endapan Aluvial merupakan endapan sungai dan limpah banjir, terdiri dari material berukuran bongkahpasir, komposisi penyusun berupa fragmen andesit, material vulkanik, terkadang dijumpai fragmen batugamping-pasiran. Intrusi Andesit, memiliki struktur sheeting joint dan columnar joint dengan kedudukan $\mathrm{N} 285^{\circ} \mathrm{E} / 80^{\circ}$ dan $\mathrm{N} 255^{\circ} \mathrm{E} / 55^{\circ}$. Pada Desa Wadas ditemukan lava andesit dengan struktur sheeting joint dan pada desa Bleber ditemukan lava andesit dengan struktur columnar joint yang memiliki persebaran setempat dan dijumpai xenolith.

Struktur geologi di daerah penelitian pada umumnya berupa kekar, dan terdapat sesar-sesar. Hasil analisis arah umum kekar menunjukkan tegasan utama berarah Baratlaut - Tenggara (N 350 E/ $\left.75^{\circ}\right)$. Sesar-sesar yang dijumpai di daerah penelitian yaitu Sesar Kali Wader I, Sesar Kali Wader II, Sesar Kali Wadas, dan Sesar Kali Bleber. Berdasarkan analisis struktur geologi mengacu pada klasifikasi Rickard (1972), Sesar Kaliwader I dan Sesar Kaliwader II, termasuk reverse left slip fault, Sesar Kali Wadas dan Sesar Kali Bleber termasuk right lateral slip fault. Peta geologi daerah penelitian dapat dilihat pada Gambar 4.

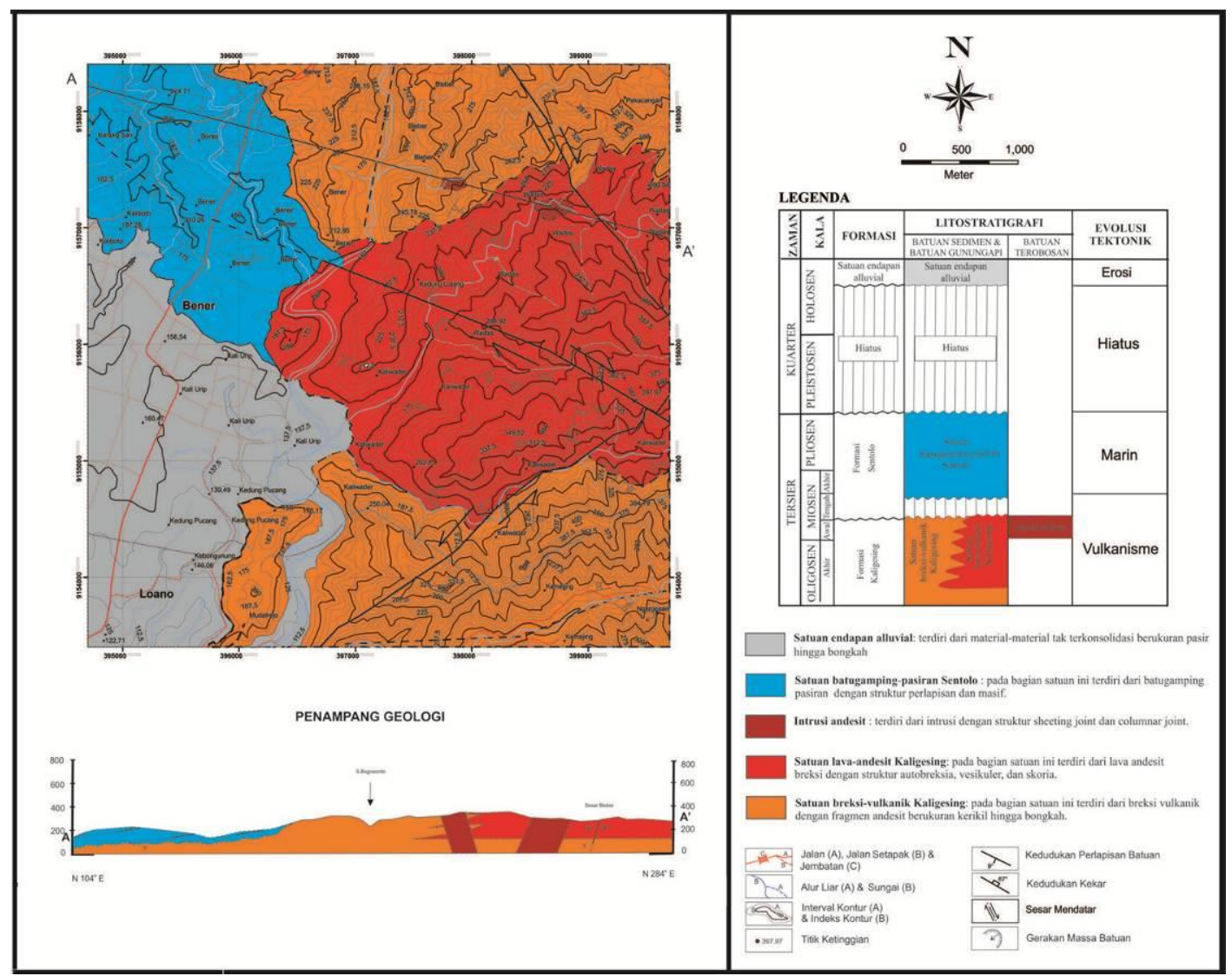

Gambar 4. Peta geologi daerah Kaliwaser dan sekitarnya

\subsection{Potensi Kandas Batuan}

Sebelum dilakukan analisis Markland terhadap 6 (enam) lereng yang merupakan sampel dalam penelitian ini, dilakukan uji sifat fisik batuan yang hasilnya sebagai berikut: Lereng Wadas dengan litologi lava andesit, nilai kohesi $391 \mathrm{Kpa}$, sudut gesek dalam 47 , Bobot isi 2.076577 (g/cm3), dan kuat tekan uniaxial 6,61871 Mpa, Lereng Kaliwader 1, litologi breksi, nilai kohesi 21,8 Kpa, sudut gesek dalam 63․ Bobot isi 1.804552 (g/cm3), dan kuat tekan uniaxial 12,4096 Mpa. Pada Lereng Kaliwader 2 dengan litologi lava andesit didapatkan nilai kohesi $15 \mathrm{Kpa}$, sudut gesek dalam 59², Bobot isi 2.076577 (g/cm3), dan kuat tekan uniaxial 6,61871 Mpa. 
Setelah itu dilakukan Rock Mass Rating (RMR) terhadap batuan penyusun lereng. Dari hasil perhitungan RMR, lereng Wadas dan lereng Kaliwader yang mempunyai nilai RMR berkisar antara 45 sampai dengan 48, termasuk klasifikasi sedang. Sementara itu hasil plot stereonet sekaligus analisis dengan metode Markland ditunjukan pada Gambar 5 hingga Gambar 10.

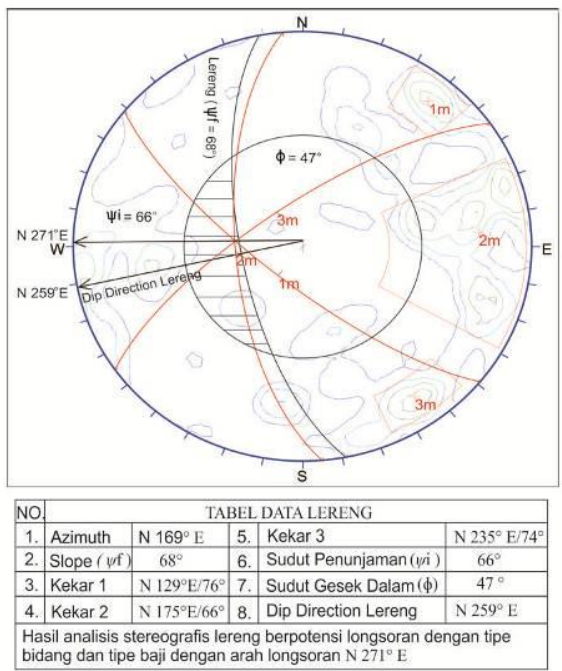

Gambar 5. Lereng Wadas, $\mathrm{N} 169^{\circ} \mathrm{E} / 68^{\circ}, 72$ pengukuran bidang kekar

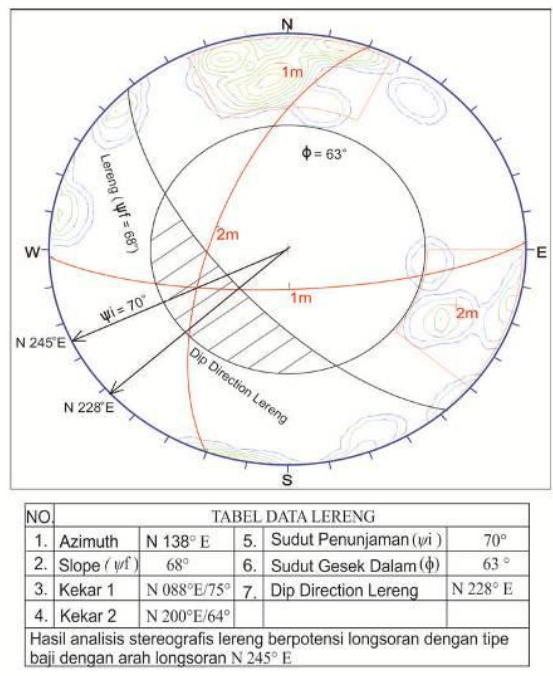

Gambar 6. Lereng Kaliwader $1, \mathrm{~N} 138^{\circ} \mathrm{E} / 68^{\circ}, 25$ pengukuran bidang kekar 


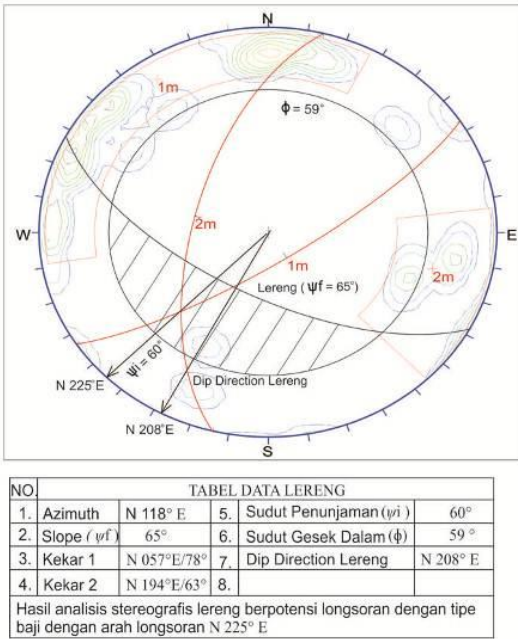

Gambar 7. Lereng Kaliwader 2, N $118^{\circ} \mathrm{E} / 65^{\circ}, 27$ pengukuran bidang kekar
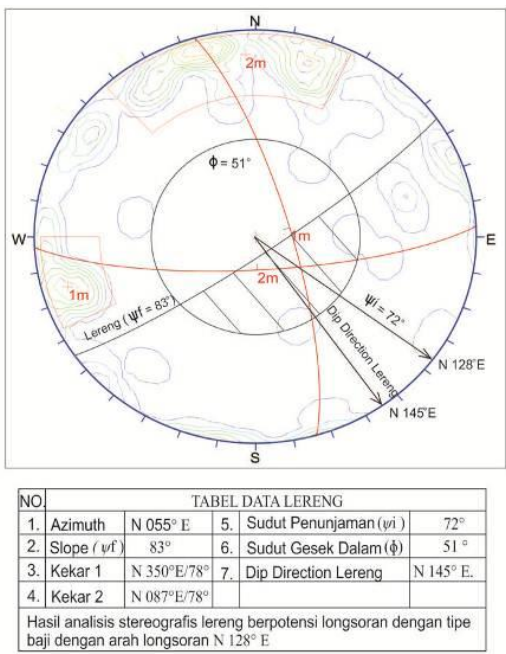

Gambar 8. Lereng Kaliwader 3, N $055^{\circ} \mathrm{E} / 83^{\circ}, 51$ pengukuran bidang kekar
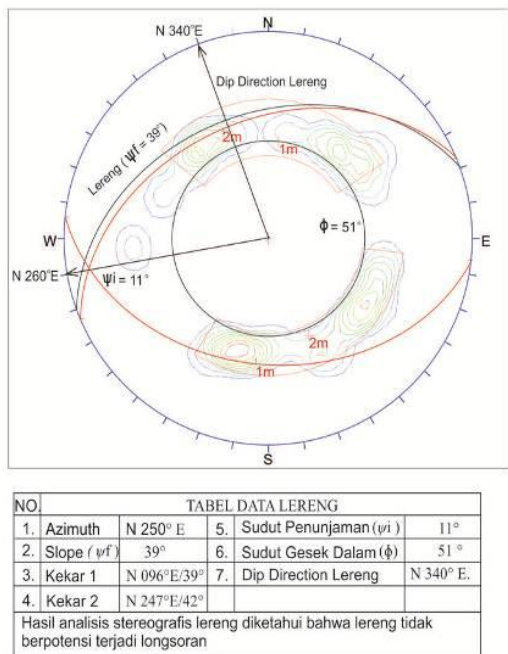

Gambar 9. Lereng Kaliwader 4, N $250^{\circ} \mathrm{E} / 39^{\circ}, 23$ pengukuran bidang kekar,

$\sim$ Sari Bahagiarti Kusumayudha, Azwar Thamrin, Heru Sigit Purwanto 


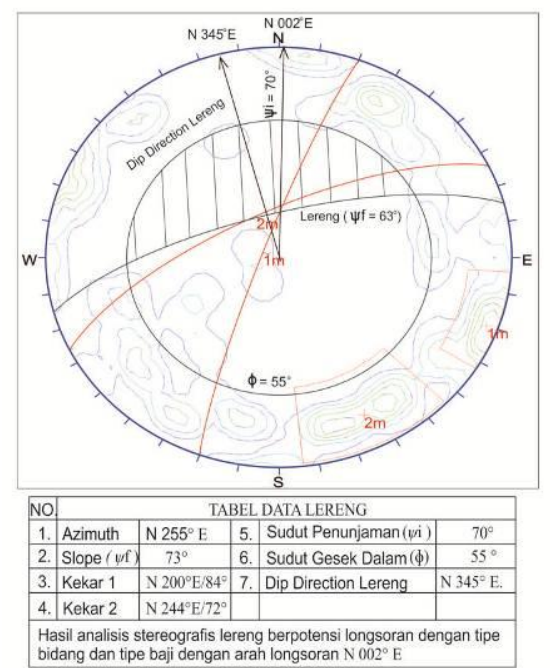

Gambar 10. Lereng Ngargosari, N $255^{\circ} \mathrm{E} / 73^{\circ} .50$ pengukuran bidang kekar

Keseluruhan hasil analisis terhadap 6 (enam) sampel lereng beserta hasil pengujian sifat fisik batuan penyusunnya disajikan dalam Tabel 1.

Tabel 1. Hasil analisis kandas batuan berdasarkan metode Markland

\begin{tabular}{lllll}
\hline No. & $\begin{array}{l}\text { Nama/Lokasi } \\
\text { Lereng }\end{array}$ & $\begin{array}{l}\text { Batuan } \\
\text { Penyusun }\end{array}$ & Nilai RMR & Tipe Potensi Kandas Batuan \\
\hline 1 & Wadas & Lava Andesit, & $\mathrm{c}=391 \mathrm{Kpa}, \mathrm{f}=66^{\circ}$, & Planar slide, arah longsor $\mathrm{N} 254^{\circ} \mathrm{E}$ \\
& & $\mathrm{g}=2.076577 \mathrm{~g} / \mathrm{cm} 3$ & Wedge, arah longsor $\mathrm{N} 271^{\circ} \mathrm{E}$ \\
& & $\mathrm{s}=6,61871 \mathrm{Mpa}$, & \\
& & $\mathrm{RMR}=48$ & \\
\hline 2 & Kaliwader 1 & Breksi & $\mathrm{c}=21,8 \mathrm{Kpa}, \mathrm{f}=63^{\circ}$, & Wedge, arah longsor $\mathrm{N} 138^{\circ} \mathrm{E}$ \\
& & Vulkanik & $\mathrm{g}=1.804552 \mathrm{~g} / \mathrm{cm} 3$, & \\
& & $\mathrm{s}=12,4096 \mathrm{Mpa}$. & \\
& & $\mathrm{RMR}=45$ & \\
\hline 3 & Kaliwader 2 & Lava Andesit & $\mathrm{c}=15 \mathrm{Kpa}, \mathrm{f}=51^{\circ}$, & \\
& & $\mathrm{g}=2.076577 \mathrm{~g} / \mathrm{cm} 3$, & \\
& & $\mathrm{s}=6,61871 \mathrm{Mpa}$. & \\
& & $\mathrm{RMR}=48$ & \\
\hline 4 & Kaliwader 3 & Lava Andesit & $\mathrm{c}=15 \mathrm{Kpa}, \mathrm{f}=51^{\circ}$, & \\
& & $\mathrm{g}=2.076577 \mathrm{~g} / \mathrm{cm} 3$, & \\
& & $\mathrm{s}=6,61871 \mathrm{Mpa}$. & \\
& & $\mathrm{RMR}=48$ & \\
& & &
\end{tabular}




\begin{tabular}{|l|l|l|l|l|}
\hline 5 & Kaliwader 4 & Lava Andesit & $\mathrm{c}=15 \mathrm{Kpa}, \mathrm{f}=55^{\circ}$, & $\begin{array}{l}\text { Planar slide, arah longsor } \\
\text { N340oE }\end{array}$ \\
& & $\begin{array}{l}\mathrm{g}=2.076577 \\
\mathrm{~g} / \mathrm{cm} 3,\end{array}$ & Wedge, arah longsor N002oE \\
& & $\mathrm{s}=6,61871 \mathrm{Mpa}$. & \\
& & $\mathrm{RMR}=47$ & \\
\hline 6 & Kaliwader 5 & Lava Andesit & $\mathrm{c}=15 \mathrm{Kpa}, \mathrm{f}=59^{\circ}$, & Wedge, arah longsor N225oE \\
& & $\begin{array}{l}\mathrm{g}=2.076577 \\
\mathrm{~g} / \mathrm{cm} 3,\end{array}$ & \\
& & $\mathrm{~s}=6,61871 \mathrm{Mpa}$. & \\
& & $\mathrm{RMR}=48$ & \\
& & & &
\end{tabular}

Keterangan: $\mathrm{c}$ : gaya kohesi, $\phi$ : sudut gesek dalam, $\gamma$ : bobot isi, $\sigma:$ kuat tekan uniaxial

Selain analisis Markland terhadap 6 sampel lereng, dalam penelitian ini dilakukan pula penentuan zonasi rawan longsor dengan metode overlaying didasarkan atas 4 (empat) parameter yaitu kemiringan lereng, litologi penyusun, kejadian longsor, dan penggunaan lahan, dengan hasil berupa peta sebagimana disajikan dalam Gambar 11.

\subsection{Penanggulangan}

Untuk mencegah kejadian longsor dalam rangka melaksanakan mitigasi bencara di daerah penelitian, antara lain dengan melakukan pelandaian lereng dan terasering. Pengendalian gerakan massa batuan dengan cara melandaikan kemiringan lereng merupakan salah satu cara yang mudah dan efisien. Melandaikan kemiringan lereng dapat dilakukan pada lereng yang terletak pada tepi jalan. Metode lain yang dapat dilakukan adalah perbaikan stabilitas batuan dengan cara penggalian batuan berbentuk trap atau bangku yang cukup efektif dan efisen diterapkan pada lereng dimana metode pertama sulit dilakukan. Hal-hal yang harus diperhatikan dalam penerapan pengendalian gerakan massa batuan dengan metode mengubah geometri lereng adalah ketersediaan biaya atau faktor keekonomian, topografi lokasi karena akan berpengaruh terhadap tingkat kesulitan dalam proses penggalian, ketersediaan peralatan dan personil. Pemahaman mengenai longsoran yang terjadi atau yang akan terjadi, penting ditanamkan kepada seluruh pemangku kepentingan serta masyarakat terutama untuk upaya mitigasi bencana di daerah tersebut.

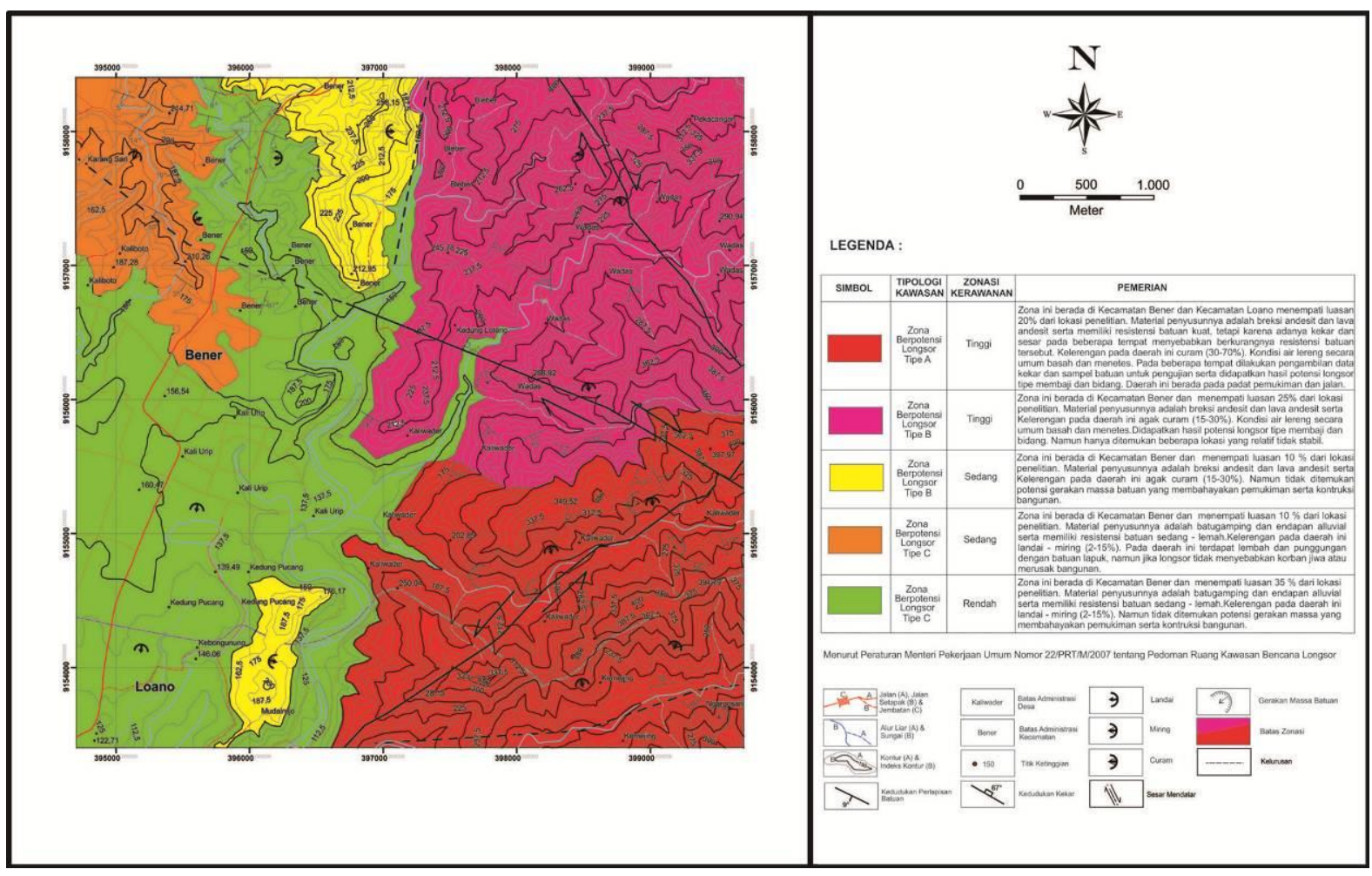

Gambar 11. Zonasi rawan longsor daerah Kaliwader dan sekitarnya 


\section{KESIMPULAN}

Kesimpulan hasil penelitian adalah sebagai berikut:

1. Geomorfologi daerah penelitian terdiri dari bentuk lahan, Perbukitan Struktural (S1), Lembah Homoklin (S2), Dataran Alluvial (F1), Tubuh Sungai (F2), dan Dataran Limpah Banjir (F3). Pola pengaliran daerah penelitian adalah Sub-dendritik, yang dikontrol oleh persebaran litologi dan struktur geologi yaitu kekar dan sesar.

2. Geologi daerah penelitian disusun oleh lima satuan dari tua ke muda yaitu Satuan Breksi-vulkanik Kaligesing, Satuan Lava-andesit Kaligesing, Satuan batugamping-pasiran Sentolo, dan Satuan endapan alluvial. Dijumpai intrusi andesit, struktur homoklin dan sesar. Sesar daerah penelitian terdiri dari Sesar Kaliwader 1, dan Sesar Kaliwader 2), berarah Timurlaut - Baratdaya, termasuk reverse left slip fault, Sesar Wadas, serta Sesar Bleber, berarah Baratlaut - Tenggara, merupakan right lateral slip fault.

3. Berdasarkan metode markland sampel-sampel lereng yang dianalisis berpotensi kandas dengan tipe planar slides dan wedge, sedangkan zona rawan longsor di daerah penelitian dapat dibagi menjadi zona dengan tingkat kerawanan tinggi, zona dengan tingkat kerawanan sedang, dan zona dengan tingkat kerawanan rendah.

\section{DAFTAR PUSTAKA}

Bieniawski, Z.T. (1989). Engineering rock mass classification: A Complete Manual For Engineers and Geologist In Mining, Civil and Petroleum Engineering, John Wiley \& Sons, Canada

Citrabhuwana, B.N.K., Kusumayudha, S.B., Purwanto. (2016). Geology and slope stability 27 analysis using markland method on road segment of Piyungan - Patuk, Sleman 28 and Gunungkidul Regencies, Yogyakarta Special Region, Indonesia. International Journal of Economic and Environmental Geology Vol 7, No 1. University of 30 Karachi, Pakistan. Diakses dari www.econ-environ-geol.org.

Dinas Pendidikan dan Kebudayaan Kabupaten Purworejo. (2006). Peta administrasi Kabupaten Purworejo.

Goodman, R.E. (1989). Introduction to rock mechanics. John Wiley \& Sons, 289p: New York, USA.

Hoek, E. and Bray, J.W. (1981). Rock Slope Engineering (3rd Ed). London: The Institution of Mining and Metallurgy.

ISRM. (1981). Commission on classification of rock masses, Basic geotechnical description of rock masses. International Journal of Rock Mechanics and Mining Sciences \& Geomechanics. Vol 1 (5) (1981), 18, 85 -110 .

Kusumayudha, S.B., Ciptahening, A.N. (2016). Correlation between tectonic environment and chracteristics of mass movement (landslides): A Case Study from Java, Indonesia, Journal of Geological resource and Engineering. Vol 4, No. 2, 51 - 62. David Publisher.

Marinos P, Hoek E. (2005). GSI: a geologically friendly tool for rock mass strength estimation. In: Proceedings of the International Conference on Geotechnical and Geological Engineering, Melbourne (pp. 14221446). Australia: Lancaster, PA: 16 Technomic Publishers.

Priest, S.D. \& Hudson J. (1976). Discontinuity spacing in rock. International Journal of Rock Mechanics and Mining Sciences \& Geomechanics. Vol 13 (5), pp. 135-148.

Rahardjo,W., Rumidi S. dan Rosidi H.M.D. (1977). Geological map of the Yogyakarta Quadrangle, Java, skala $1: 100.000$. Geological Survey of Indonesia. 1-15.

Rickard, M. J.. (1972). Classification of Translational Fault Slip: Geological Society of America. 